\title{
PENINGKATAN KOMPONEN HASIL DAN MUTU BENIH KACANG TANAH (Arachis hypogaea L.) MELALUI PEMUPUKAN BOKASHI DAN P
}

Increasing Yield and Seed Quality of Peanut (Arachis hypogaea L.) by Bokashi and P Fertilizing

\author{
Nadia Safira ${ }^{1) *}$, Sumadi $^{1)}$, Denny Sobardini Sobarna ${ }^{1)}$ \\ ${ }^{1)}$ Program Studi Agroteknologi, Fakultas Pertanian, Universitas Padjadjaran \\ Jalan Raya Jatinangor Km. 21 Jatinangor, Sumedang 45363 \\ *E-mail: safiranadia155@gmail.com
}

\begin{abstract}
Peanuts are a potential commodity to be developed in Indonesia after soybeans and green beans. Low peanuts seed production is an existing problem that must be solved, with one of the ways is fertilizing bokashi and $P$. The purpose of this study is to determine the effect of the interaction of bokashi and $P$ fertilizer application on yield and seed quality of peanuts (Arachis hypogaea L.). The experiment was started from Desember 2016 to April 2017, at the Ciparanje Experiment Field and Seed Technology Laboratory of the Faculty of Agricalture, University of Padjadjaran, Jatinangor, Sumedang, West Java. The experiment design used is a pattern of factorial randomized block design with two factors and three replication. The first factor is the dose of bokashi fertilizer with three levels, 0 5, 10 ton $\mathrm{ha}^{-1}$ and the second factor is the dose of $P$ fertilizer with four levels, 0, 50, 75, 100 $\mathrm{kg} \mathrm{ha}^{-1}$. The result showed that there is no interaction between bokashi and $P$ on all of parameters. Application of Bokashi fertilizer and $P$ fertilizer significantly on yield but not significantly on seed quality parameter. Bokashi fertilizer has an effect on increasing the weight of seeds per plant. Bokashi fertilizer with dose 5 ton $\mathrm{ha}^{-1}$ gave the best influence to the weight of seeds per plant. Effect of application of $P$ fertilzer with dose $50 \mathrm{~kg} \mathrm{ha}^{-1}$ gave the best effect on harvest index parameter.
\end{abstract}

Keywords : bokashi, peanuts, phospahate fertilizer, seed quality

\section{PENDAHULUAN}

Kacang tanah merupakan komoditas yang potensial untuk dikembangkan di Indonesia setelah kedelai dan kacang hijau. Kacang tanah dapat menjadi sumber protein nabati, bahan baku industri makanan, kebutuhan rumah tangga, dan diolah langsung. Permintaan akan kacang tanah terus meningkat seiring dengan meningkatnya jumlah penduduk di Indonesia, sehingga membutuhkan ketersediaan yang cukup baik kualitas maupun kuantitas (Kementrian Pertanian, 2016).

Kebutuhan rata - rata kacang tanah di Indonesia setiap tahunnya mencapai \pm 816 ribu ton, sedangkan produksi dalam negeri sebesar 638.896 ton (Kementrian Pertanian, 2016). Produksi dalam negeri yang rendah disebabkan oleh beberapa faktor antara lain yaitu penggunaan varietas lokal yang bukan varietas unggul dan penggunaan benih bermutu tetapi pemeliharaan tanamannya kurang tepat dalam produksi kacang tanah (Paturohman dan Sumarno, 2014). Berdasarkan hal tersebut maka penting dilakukan upaya peningkatan produksi agar dapat memenuhi kebutuhan kacang tanah di Indonesia.

Upaya yang dapat dilakukan untuk meningkatkan produksi kacang tanah dalam negeri adalah penggunaan benih varietas unggul yang berkualitas tinggi diiringi dengan aplikasi teknik budidaya tanaman yang tepat. Salah satu upaya pemeliharaan tanaman yang dapat dilakukan adalah pemupukan, baik organik maupun anorganik.

Bokashi merupakan hasil fermentasi bahan organik dengan pemberian EM4 (Effective Mikroorganisme - 4), sehingga kualitas bokashi lebih baik dari pada pupuk organik lainnya. Pemberian bokashi 
akan mempengaruhi sifat fisik dan kimia tanah. Pengaruh pemberian bokashi terhadap sifat fisik tanah yaitu dapat meningkatkan porositas tanah dan kemampuan tanah dalam mengikat air sehingga dapat meningkatkan pertumbuhan tanaman sedangkan terhadap sifat kimia tanah, bokashi dapat meningkatkan kapasitas tukar kation (KTK), pH tanah dan keharaan tanah (Sedjati, 2010).

Bokashi mengandung bakteri bakteri menguntungkan yang berasal dari EM4 (Effective Microorganism - 4). Menurut penelitian Maemunah et al. (2017), bakteri - bakteri yang terkandung dalam EM4 adalah bakteri pelarut fosfat, Lactobacillus sp., Yeast, Actinomycetes, dan bakteri fotosintesis. Kandungan bakteri pelarut fosfat pada bokashi dapat membantu pelarutan pupuk $\mathrm{P}$ yang diberikan dalam tanah. Setelah pupuk $\mathrm{P}$ terlarut, tanaman dapat menyerap unsur $\mathrm{P}$ untuk pertumbuhannya.

Fosfat penting untuk pembelahan sel, pembentukan albumin, pembentukan bunga, buah, dan biji, mempercepat pematangan buah dan biji, perkembangan akar, metabolisme karbohidrat, serta menyimpan dan memindahkan energi. Pada kacang tanah kegunaan pupuk fosfat yaitu mendorong awal perkembangan akar, pembentukan bunga dan biji, memperbesar persentase terbentuknya bunga menjadi biji, menambah daya tahan tanaman terhadap serangan hama dan penyakit, serta memperbaiki struktur tanah (Marzuki, 2007).

Fosfat dalam benih akan disimpan dalam bentuk fitin yang kemudian dirombak sebagai sumber energi untuk perkecambahan dan pertumbuhan kecambah sehingga dapat memperbaiki perkecambahan (Widajati et al., 2012).

$$
\text { Penelitian Sedjati }
$$
menyimpulkan bahwa pemberian bokashi jerami padi dan pupuk $\mathrm{P}$ berpengaruh nyata terhadap peningkatan pertumbuhan dan hasil kacang tanah.
Hasil penelitian Rasyid (2013) menyimpulkan bahwa pemberian pupuk $\mathrm{P}$ berpengaruh terhadap kandungan cadangan makanan pada benih kedelai yang berupa glukosa, lemak, dan protein. Glukosa sebagai cadangan makanan akan mempengaruhi kualitas benih. Kandungan lemak yang tinggi menunjukkan sumber energi yang tinggi pula sehingga dapat digunakan untuk perkecambahan benih yang nantinya memengaruhi viabilitas benih yang tinggi.

Pemupukan dengan bokashi dan $\mathrm{P}$ diharapkan dapat meningkatkan ketersediaan unsur $\mathrm{P}$ untuk tanaman. Berdasarkan latar belakang tersebut, maka perlu dilakukan penelitian lebih lanjut tentang pengaruh pupuk bokashi dan $\mathrm{P}$ terhadap mutu benih kacang tanah.

\section{METODE PENELITIAN}

\section{Alat dan Bahan}

Alat yang digunakan yaitu polybag, kertas merang, plastik, ember plastik, alat penyiram, sekop, cangkul, ayakan, kored, tugal, sprayer untuk pestisida, kertas label, timbangan analitik, sprayer, tali rapia, germinator, kamera, dan alat tulis.

Bahan yang digunakan yaitu benih kacang tanah varietas Kancil yang diperoleh dari Balai Penelitian KacangKacangan dan Umbi-Umbian Malang, bokashi jerami padi sesuai dosis, pupuk SP-36 dan pupuk dasar (urea dan $\mathrm{KCl}$ ) sesuai dosis, tanah Inceptisol, air, Furadan 3G (bahan aktif karbofuran 3\%) dan pestisida.

\section{Tahapan Penelitian}

\section{Persiapan media tanam}

Tanah ditimbang seberat $15 \mathrm{~kg}$ untuk setiap polybagnya. Setelah itu diberi pupuk bokashi sesuai dengan perlakuan. Media diinkubasikan selama tujuh hari dan disiram setiap hari untuk mempertahankan kapasitas lapang dan mempercepat proses dekomposisi. Setelah diinkubasikan 
selama 7 hari media tanam sudah siap untuk ditanami.

\section{Penanaman}

Benih diberi furudan 3G (karbofuran $3 \%$ ) sebelum ditaman. Pemberian 3G berfungsi untuk mencegah benih dari serangan cendawan. Setelah siap ditanami, dibuat lubang tanah sedalam 3-5 cm. Benih kacang varietas Kancil dimasukkan dalam lubang sebanyak 3 butir per polybag kemudian disiram.

\section{Pemeliharaan}

Pemeliharaan yang dilakukan yaitu pemupukan dasar, penyiraman dan pengendalian OPT. Pemupukan dasar dilakukan pada 1 minggu setelah tanam. Penyiraman dilakukan saat dibutuhkan karena penelitian dilakukan saat musim hujan. Pengendalian OPT dilakukan dengan manual dan pestisida.

\section{Pemanenan}

Panen dilakukan pada umur tanaman 97 hari setelah penanaman dengan ciri-ciri visual yaitu daun-daun telah menguning dan kering. Pemanenan dapat dilakukan dengan cara dicabut secara perlahan.

\section{Pengujian mutu benih}

Pengujian mutu benih dilakukan di Laboratorium Teknologi Benih Fakultas Pertanian Universitas Padjadjaran. Pengujian daya berkecambah dilakukan dengan menggunakan metode UKDp (Uji Kertas Digulung Plastik).

\section{Rancangan Percobaan}

Percobaan ini dilakukan dengan menggunakan Rancangan Acak Kelompok (RAK) pola faktorial yang terdiri dari 2 faktor dan 3 ulangan. Faktor pertama, dosis pupuk bokashi yaitu b0 = tanpa bokashi, b1 $=5$ ton ha ${ }^{-1}$, dan $\mathrm{b} 2=10$ ton $\mathrm{ha}^{-1}$. Faktor kedua, dosis pupuk $\mathrm{P}$ yaitu $\mathrm{p} 0=$ tanpa pupuk $\mathrm{P}, \mathrm{p} 1=50 \mathrm{~kg} \mathrm{ha}^{-1}, \mathrm{p} 2=$ $75 \mathrm{~kg} \mathrm{ha}^{-1}$, dan $\mathrm{p} 3=100 \mathrm{~kg} \mathrm{ha}^{-1}$.

\section{Metode Analisis}

Data pengamatan dianalisis dengan uji anova. Hasil yang berbeda nyata dilanjutkan dengan uji lanjut jarak berganda Duncan dengan taraf 5\%.

\section{HASIL DAN PEMBAHASAN}

\section{Komponen Hasil}

Parameter komponen hasil yang diamati adalah bobot biji per tanaman dan indeks panen. Hasil perhitungan uji $\mathrm{F}$ pada

Tabel 1. Pengaruh penggunaan bokashi dan pupuk $\mathrm{P}$ terhadap Bobot biji per tanaman dan indeks panen

\begin{tabular}{|c|c|c|}
\hline Perlakuan & Bobot biji per tanaman (g) & Indeks Panen \\
\hline \multicolumn{3}{|l|}{ Bokashi } \\
\hline b0 (Tanpa Bokashi) & $27,08 \mathrm{a}$ & 0,45 \\
\hline b1 (Bokashi 5 ton ha $^{-1}$ ) & $33,77 \mathrm{~b}$ & 0,45 \\
\hline b2 (Bokashi 10 ton $\mathrm{ha}^{-1}$ ) & $29,88 \mathrm{a}$ & 0,46 \\
\hline \multicolumn{3}{|l|}{ Pupuk P } \\
\hline p0 (Tanpa Pupuk P) & 29,95 & $0,43 \mathrm{ab}$ \\
\hline p1 (Pupuk P $50 \mathrm{~kg} \mathrm{ha}^{-1}$ ) & 31,28 & $0,49 \mathrm{c}$ \\
\hline p2 (Pupuk P $75 \mathrm{~kg} \mathrm{ha}^{-1}$ ) & 20,02 & $0,47 \mathrm{bc}$ \\
\hline p3 (Pupuk P $100 \mathrm{~kg} \mathrm{ha}^{-1}$ ) & 29,71 & $0,42 \mathrm{a}$ \\
\hline
\end{tabular}

Keterangan: Nilai rata - rata yang diikuti huruf yang sama pada kolom yang sama tidak berbeda nyata menurut uji jarak berganda Duncan pada taraf 5\%. 
taraf 5\% menunjukkan bahwa tidak terdapat interaksi antara bokashi dan pupuk $\mathrm{P}$ terhadap bobot biji per tanaman dan indeks panen. Pemberian pupuk bokashi berpengaruh nyata terhadap bobot bii per tanaman. Pemberian pupuk $\mathrm{P}$ memberikan pengaruh nyata terhadap indeks panen (Tabel 1).

Berdasarkan Tabel 1 dapat dilihat bahwa pemberian bokashi berpengaruh nyata terhadap bobot biji per tanaman dan pemberian $\mathrm{P}$ berpengaruh nyata terhadap indeks panen. Pemberian bokashi berpengaruh nyata terhadap bobot biji per tanaman. Perlakuan bokashi 5 ton $\mathrm{ha}^{-1}$ berbeda nyata dengan perlakuan tanpa bokashi dan bokashi 10 ton $\mathrm{ha}^{-1}$. Hal tersebut diduga karena bokashi dengan dosis 5 ton ha $^{-1}$ merupakan dosis yang sesuai untuk pertumbuhan dan produksi kacang tanah. Hal tersebut didukung oleh Salisbury dan Ross (1995) yang menyatakan bahwa tiap jenis tumbuhan menyerap unsur dalam jumlah yang berbeda serta sesuai dengan penelitian Sedjati (2010) yang menyimpulkan bahwa bokashi dengan dosis 5 ton ha $^{-1}$ efektif dalam peningkatan produksi kacang tanah.

Pemberian pupuk $\mathrm{P}$ tidak berpengaruh nyata terhadap bobot biji per tanaman. Hal itu diduga karena kandungan $P$ pada tanah yang digunakan sudah tinggi sehingga pupuk $\mathrm{P}$ yang diberikan tidak digunakan secara efisien untuk pertumbuhan tanaman. Menurut Sumarno (2013) menyatakan bahwa apabila dilakukan pemupukan $\mathrm{P}$ dan $\mathrm{K}$ pada tanah dengan kadar fosfat dan kalium tinggi, maka sebagian besar pupuk tidak digunakan secara efisien.

Selain itu, pada saat pembentukan biji diduga unsur $\mathrm{P}$ yang diberikan tidak terlarut semua dan tidak dapat diserap karena kemungkinan adanya fiksasi unsur $\mathrm{P}$ yang diberikan di dalam tanah. Menurut Rosmarkam dan Yuwono (2006) fiksasi P menyebabkan $\mathrm{P}$ yang tersedia bagi tanaman menjadi tidak tersedia. Fiksasi yang biasanya terjadi adalah fiksasi oleh ion $\mathrm{Fe}$ dan $\mathrm{Al}$, fiksasi oleh $\mathrm{CaCO}_{3}$ pada tanah alkalis dan reaksi fosfat dengan lempung. Fiksasi yang mungkin terjadi adalah fiksasi oleh ion $\mathrm{Fe}$ dan $\mathrm{Al}$ karena $\mathrm{pH}$ termasuk agak masam pada saat analisis awal dan sangat memungkinkan untuk terjadi perubahan $\mathrm{pH}$ saat pertumbuhan tanaman.

Pemberian pupuk $\mathrm{P}$ berpengaruh nyata terhadap indeks panen. Perlakuan tanpa pupuk $\mathrm{P}$ berbeda nyata terhadap perlakuan pupuk $\mathrm{P} 50 \mathrm{~kg} \mathrm{ha}^{-1}$, tetapi tidak berbeda nyata dengan perlakuan pupuk $\mathrm{P}$ $75 \mathrm{~kg} \mathrm{ha}^{-1}$ dan pupuk P $100 \mathrm{~kg} \mathrm{ha}^{-1}$. Perlakuan pupuk P $50 \mathrm{~kg} \mathrm{ha}^{-1}$ tidak berbeda nyata dengan perlakuan pupuk $\mathrm{P}$ $75 \mathrm{~kg} \mathrm{ha}^{-1}$ akan tetapi berbeda nyata dengan perlakuan pupuk $100 \mathrm{~kg} \mathrm{ha}^{-1}$. Hal itu diduga karena pemberian pupuk $\mathrm{P} 100$ $\mathrm{kg} \mathrm{ha}^{-1}$ tidak diserap secara optimum oleh tanaman yang dapat disebabkan adanya fiksasi P. Menurut Rosmarkam dan Yuwono (2006) fiksasi P menyebabkan P yang tersedia bagi tanaman menjadi tidak tersedia.

Penelitian Hanum (2013) menghasilkan indeks panen tanaman kedelai sebesar 0,54\% yang berarti $54 \%$ hasil fotosintesis disalurkan kedalam biji. Pada perlakuan p1 indeks panen sebesar 0,49 , jika sesuai dengan penelitian Hanum (2013) , maka hal itu berarti 49\% dari hasil fotosintesis disalurkan ke dalam biji. Unsur P berpengaruh terhadap pembentukan bunga, buah dan biji. Selain itu, unsur $\mathrm{P}$ dapat berfungsi untuk menyimpan dan memindahkan energi yang digunakan untuk proses fotosintesis (Hardjowigeno, 2010).

\section{Mutu Benih}

Parameter mutu benih yang diamati meliputi mutu fisik dan mutu fisiologis benih. Mutu fisik yang diamati berupa bobot 100 butir, sedangkan mutu fisiologis benih yang diamati berupa daya berkecambah $(\%)$ dan indeks vigor. Hasil perhitungan uji $\mathrm{F}$ pada taraf $5 \%$ menunjukkan bahwa tidak terdapat 
Tabel 2. Pengaruh penggunaan bokashi dan pupuk $\mathrm{P}$ terhadap Bobot 100 butir, daya berkecambah (\%) dan indeks vigor

\begin{tabular}{|c|c|c|c|}
\hline Perlakuan & $\begin{array}{c}\text { Bobot } \\
100 \text { butir (g) }\end{array}$ & Daya Berkecambah (\%) & Indeks Vigor \\
\hline \multicolumn{4}{|l|}{ Bokashi } \\
\hline b0 (Tanpa Bokashi) & 40,14 & 86,88 & 6,67 \\
\hline b1 (Bokashi 5 ton $\mathrm{ha}^{-1}$ ) & 43,30 & 84,75 & 6,49 \\
\hline b2 (Bokashi 10 ton ha ${ }^{-1}$ ) & 42,24 & 85,83 & 6,88 \\
\hline \multicolumn{4}{|l|}{ Pupuk P } \\
\hline p0 (Tanpa pupuk P) & 42,72 & 81,11 & 6,23 \\
\hline p1 ( Pupuk P $50 \mathrm{~kg} \mathrm{ha}^{-1}$ ) & 43,95 & 87,22 & 6,92 \\
\hline p2 (Pupuk P $75 \mathrm{~kg} \mathrm{ha}^{-1}$ ) & 39,82 & 85,83 & 6,56 \\
\hline p3 ( Pupuk P $100 \mathrm{~kg} \mathrm{ha}^{-1}$ ) & 41,09 & 89,11 & 7,00 \\
\hline
\end{tabular}

Keterangan: Tidak dilakukan Uji Jarak Berganda Duncan pada taraf nyata 5\% karena tidak berpengaruh nyata menurut analisis ragam.

interaksi antara bokashi dan pupuk $\mathrm{P}$ terhadap bobot 100 butir, daya berkecambah (\%), dan indeks vigor. Pemberian pupuk bokashi dan pupuk $\mathrm{P}$ tidak memberikan pengaruh nyata secara mandiri terhadap parameter mutu benih (Tabel 2).

Berdasarkan Tabel 2 dapat dilihat bahwa pemberian bokashi dan pupuk $\mathrm{P}$ tidak berpengaruh nyata terhadap bobot 100 butir, daya berkecambah (\%) dan indeks vigor. Perlakuan bokashi tidak berpengaruh nyata diduga karena kandungan bahan organik pada bokashi yang rendah menyebabkan tidak berpengaruh terhadap parameter pengamatan. Pupuk organik mengandung hara yang lengkap walaupun kadarnya tidak setinggi pupuk anorganik (Lingga dan Marsono, 2000).

Pemberian Pupuk $\mathrm{P}$ tidak berpengaruh nyata terhadap bobot 100 butir, daya berkecambah (\%) dan indeks vigor diduga karena kandungan $\mathrm{P}$ pada tanah yang digunakan sudah tinggi sehingga pupuk $\mathrm{P}$ yang diberikan tidak digunakan secara efisien untuk pertumbuhan tanaman. Menurut Sumarno (2013) menyatakan bahwa apabila dilakukan pemupukan $\mathrm{P}$ dan $\mathrm{K}$ pada tanah dengan kadar fosfat dan kalium tinggi, maka sebagian besar pupuk tidak digunakan secara efisien.

Benih yang dihasilkan dapat dikatakan memiliki mutu yang tinggi. Pengujian daya berkecambah menghasilkan rata - rata daya berkecambah di atas $80 \%$. Hal itu sesuai dengan ketentuan pengujian benih ISTA (2003) yang menyatakan bahwa salah satu kriteria benih bermutu adalah nilai daya berkecambah yang tinggi minimal $80 \%$.

Selain itu, vigor benih yang dihasilkan juga dapat dikatakan cukup baik. Indeks vigor benih pada semua perlakuan berkisar antara 6,23 - 7,00. Indeks vigor ini dapat dikatakan cukup mendekati indeks vigor maksimal yaitu 8 . Hal ini diduga karena pegujian dilakukan langsung setelah benih masak sehingga benih mencapai vigor maksimum sesuai dengan pernyataan Widajati et al. (2013) bahwa pada fase pemasakan benih mencapai masak fisiologis dimana berat kering, viabilitas dan vigor maksimum.

\section{KESIMPULAN}

Perlakuan bokashi dan pupuk P tidak memberikan pengaruh interaksi terhadap semua parameter pengamatan. Pemberian bokashi berpengaruh meningkatkan bobot biji per tanaman. Dosis bokashi 5 ton ha ${ }^{-1}$ 
memberikan hasil terbaik pada bobot biji per tanaman. Perlakuan $\mathrm{P}$ meningkatkan indeks panen. Dosis $50 \mathrm{~kg} \mathrm{ha}{ }^{-1}$ memberikan hasil terbaik pada indeks panen. Pemberian bokashi dan $\mathrm{P}$ tidak memberikan pengaruh nyata terhadap mutu benih

\section{DAFTAR PUSTAKA}

Adisarwanto,T. 2000. Meningkatkan Produksi Kacang Tanah di Lahan Sawah dan Lahan Kering. Penebar Swadaya, Jakarta.

BPS. 2016 . Produksi Kacang Tanah Menurut Provinsi (Ton) $1993-2015$. (https://www.bps.go.id). (Diakses tanggal 15 September 2016)

. 2016. Luas Panen Kacang Tanah Menurut Provinsi (ha) 1993 - 2015. (https://www.bps.go.id ). (Diakses tanggal 15 September 2016)

Hanum. 2013. Pertumbuhan, hasil dan mutu biji kedelai dengan pemberian pupuk organik dan fosor. J. Agron. Indonesia, 41 (3): 209-214.

Hardjowigeno, S. 2010. Ilmu Tanah. Akademika Pressindo, Jakarta

ISTA. 2003. International Rules for Seed Testing. The International Seed Testing Association (ISTA). Bassedort, C-H Switzerland.

Kementrian Pertanian. 2016. Petunjuk Teknis Pengelolaan Produksi Kacang Tanah dan Kacang Hijau. Kementrian Pertanian Direktorat Jenderal Tanaman Pangan. (www.tanamanpangan.pertanian.go.id) (Diakses tanggal 15 September 2016).

Lingga, P., dan Marsono. 2000. Petunjuk Penggunaan Pupuk. Penebar Swadaya, Jakarta.

Marzuki, R. 2007. Bertanam Kacang Tanah. Penebar Swadaya, Jakarta.
Maemunah, A. Anhar dan L. Advinda. 2017. Pengaruh kombinasi Pseudomonas flouresen dan EM4 dalam menghambat Blood Disease Bacteria (BDB) penyebab penyakit darah tanaman pisang secara in vitro. Journal UNP, 1 (1): 70-77.

Paturohman, E dan Sumarno. 2014. Peningkatan Produktivitas Kacang Tanah Melalui Penerapan Komponen Teknologi Kunci. Pusat Penelitian dan Pengembangan Tanaman Pangan, Bogor.

Rasyid, H. 2013. Peningkatan produksi dan mutu benih kedelai varietas hitam unggul nasional sebagai fungsi jarak tanam dan pembeian dosis pupuk $\mathrm{P}$. Jurnal Gamma, 8 (2): 46 -63.

Salisbury, F. B dan C. W. Ross. 1995 Fisiologi Tumbuhan Jilid 1. Diterjemahkan oleh Diah R Lukman dan Sumaryono. Penerbit ITB, Bandung.

Sedjati, S. 2010. Kajian pemberian bokashi jerami padi dan pupuk $\mathrm{P}$ pada kacang tanah(Arachis hypogaea L.). Jurnal Sains dan Teknologi, 3 (2): 1-11.

Sumarno. 2013. Pupuk dan Pemupukan Ramah Lingkungan. Jurusan Ilmu Tanah Fakultas Pertanian UB, Malang.

Widajati, E, E. Murniati, E. R. Palupi, T. Kartika, M. R. Suhartanto, dan A. Qadir. 2012. Dasar Ilmu dan Teknologi Benih. IPB Press, Bogor. 